\title{
STUDIES ON FEEDING GREEN BERSEEM (Trifolium alexandrinum) ON GROWTH PERFORMANCE AND ECONOMICS OF FINISHER PIGS RAISED ON KITCHEN WASTE BASED DIET
}

\author{
Ravindra Kumar ${ }^{1, *}$ and M. Patel ${ }^{2}$
}

\begin{abstract}
${ }^{1}$ Scientist - cum -Assistant professor, Department of Livestock production and management, Ranchi Veterinary college, Kanke, Ranchi, Jharkhand
${ }^{2}$ Sr. Scientist, Department of Livestock Production \& Management, Indian Veterinary Research Institute, Bareilly, Uttar Pradesh
\end{abstract}

Received - August 17, 2016; Revision - September 19, 2016; Accepted - September 27, 2016

Available Online - October 13, 2016

DOI: http://dx.doi.org/10.18006/2016.4(Spl-2-SSPN).S48.S52

KEYWORDS
Berseem
Economics
Growth
Kitchen waste
Pig

\begin{abstract}
Present experiment was designed to study performance of large white yorkshire pigs of the age of about 5 months by feeding kitchen waste based diet. Animals were segregated and kept in 4 different groups comprising of 6 animals in each category. Each group received feed as follows, group I : 10\% green berseem $+50 \%$ kitchen waste $+40 \%$ concentrate; Group II: $15 \%$ green berseem $+50 \%$ kitchen waste + $35 \%$ concentrate; Group III: $20 \%$ green berseem $+50 \%$ kitchen waste $+30 \%$ concentrate and group IV: $25 \%$ green berseem $+50 \%$ kitchen waste $+25 \%$ concentrate. The feeding trial was conducted for two months duration with green berseem and concentrate with variable ratio while kitchen waste was kept constant. Dry matter intake was found significantly $(\mathrm{P}<0.01)$ higher in group I and no significant differences were observed among group II, III and IV. With respect to parameter of overall bodyweight gain difference was not significant during finishing stage of experimental animals. But in Group I animals the last fortnight period had shown significant $(\mathrm{P}<0.05)$ change in bodyweight gain. Further, daily weight gain was found significant in Group I animals and it was not noticed in other groups. Concentrate substitution for 50\% kitchen waste along with different levels of green berseem decreased feed conversion ratio. But these differences were not found significant among experimental groups. Significant $(\mathrm{P}<0.01)$ difference in cost of total feed intake and cost per $\mathrm{kg}$ live weight gain were observed and was found highest in Group I followed by Group II, III and IV. The study also noticed that no significant difference between group II and III.
\end{abstract}

* Corresponding author

E-mail: ravindrakumar_rvc@yahoo.com(Ravindra Kumar)

Peer review under responsibility of Journal of Experimental Biology and Agricultural Sciences.

Production and Hosting by Horizon Publisher India [HPI] (http://www.horizonpublisherindia.in/).

All rights reserved.
All the article published by Journal of Experimental Biology and Agricultural Sciences is licensed under a Creative Commons Attribution-NonCommercial 4.0 International License Based on a work at www.jebas.org.

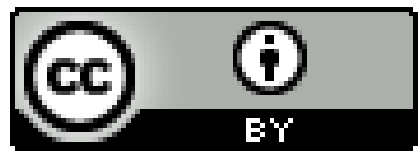




\section{Introduction}

Livestock production systems in India are mainly based on low cost agro by products as nutritional input through traditional technologies or practices. This augurs well in pig production system as agro-industrial byproducts unfit for human consumption or forages can be nutritional source for these livestock. However, cost of feed accounts as high as 70-75 percent of total expenditure in pig farming (ICAR, 2002). Hence, any endeavour for lowering production cost in pig farming is paramount, with emphasize on economic feasibility of feed as being the single cost factor. It is also felt not only to optimize growth of animals by providing them with diets of optimum quality but with maximum economic return for smallholder livestock producers. Accordingly, present research was planned to observe effect of kitchen wastes and green pasture, in place of concentrate to the extent feasible in pig ration without adversely affecting performance.

\section{Materials and Methods}

Present investigation was conducted at Swine Production Unit, Department of Livestock Production and Management, College of Veterinary and Animal Sciences, G.B. Pant University of Agriculture \& Technology, Pantnagarduring the year 2010 . Experiment was designed using 24 piglets of about 5 months age. Animals were randomly selected and kept in 4 groups $\left(T_{1}\right.$, $\mathrm{T}_{2}, \mathrm{~T}_{3}$ and $\mathrm{T}_{4}$ ) of 6 animals each. The experimentation was conducted for a period of two months. Distributions of feed in different such groups have been presented as follows, Group I: $10 \%$ green berseem $+50 \%$ kitchen waste $+40 \%$ concentrate; Group II: $15 \%$ green berseem $+50 \%$ kitchen waste $+35 \%$ concentrate; Group III: $20 \%$ green berseem $+50 \%$ kitchen waste $+30 \%$ concentrate and Group IV: $25 \%$ green berseem + $50 \%$ kitchen waste $+25 \%$ concentrate. Green berseem and concentrate was variable while kitchen waste was kept constant in the study. The ad libitum feeding was done during experiment. The voluntary feed intake of each animal was recorded daily. Change in body weight was recorded in the morning before feeding at every fortnight interval by using standard balance. The green Berseem (Trifolium alexendrium) required for research work was harvested, chopped and allowed wilting for overnight before feeding. The kitchen waste was collected from hostel mess in fresh form. Thereafter, it was thoroughly mixed to make it uniform in its contents.
The cost of balanced ration, green berseem and kitchen waste was calculated by including transportation cost from production unit to experimental site. The relative cost effectiveness of each diet was assessed accordingly. By considering total live weight gain under each treatment, the cost involved to produce $1 \mathrm{~kg}$ live weight gain was calculated. Net profit for each treatment was calculated separately by considering sale price of pork produced at the end of experiment. The data were analyzed using Analysis of Variance (ANOVA) and the Critical Difference (CD) to determine any significant difference among the treatment means (Snedecor \& Cochran, 1994).

\section{Results and Discussion}

The chemical composition of feed ingredients and proximate composition (\% on DM basis) of experimental diets were presented in Table $1 \& 2$, respectively. The dry matter, organic matter, ether extract and nitrogen free extract was found highest for group I followed by group II, III and IV. However, total ash, crude protein and crude fibre was found highest for group IV followed by group III, II and I.

The average daily dry matter intake $(\mathrm{kg})$ in finisher pigs is presented in Table 3. The overall daily DM intake during finishing stage was $3.14 \pm 0.04,2.20 \pm 0.03,2.18 \pm 0.04$ and $2.12 \pm 0.04 \mathrm{~kg}$ respectively, in groups I, II, III, and IV. Significantly $(\mathrm{P}<0.01)$ highest overall $\mathrm{DM}$ intake during finishing stage was found in group I followed by group II, III and IV. However, no significant differences were observed among group II, III and IV. During $1^{\text {st }}$ to last week $\left(8^{\text {th }}\right)$ of the finishing stage significant $(\mathrm{P}<0.01)$ difference were observed among groups. During entire finishing stage significantly highest DM intake was observed for group I followed by group II, III and IV. However no significant differences were observed among later three groups in most of the period. Result clearly indicated that as the percentage of berseem increases in diet, DM consumption decreases accordingly. Thus significantly $(\mathrm{P}<0.01)$ highest $\mathrm{DM}$ intake was observed for group I having least green berseem (10\%) in diet. These findings might be due to bulky nature of fodder green berseem and low capacity of alimentary canal in pigs. These findings of present study are in agreement with Yadav et al. (1990), Yadav et al. (1993), Geethapriya et al. (2006) and Phiny et al. (2010).

Table 1 Chemical composition of in concentrate mixture, kitchen waste and green berseem (\% on DM basis).

\begin{tabular}{|l|c|c|c|}
\hline Constituent & Concentrate mixture & Kitchen waste & Green berseem \\
\hline Dry matter & $90.17 \pm 0.56$ & $29.67 \pm 3.52$ & $14.20 \pm 0.85$ \\
\hline Organic matter & $90.69 \pm 0.73$ & $95.80 \pm 0.86$ & $85.09 \pm 0.36$ \\
\hline Crude protein & $20.00 \pm 1.01$ & $19.07 \pm 0.58$ & $21.68 \pm 2.29$ \\
\hline Crude fibre & $3.20 \pm 1.63$ & $2.39 \pm 1.38$ & $18.69 \pm 0.86$ \\
\hline Ether extract & $3.59 \pm 0.53$ & $12.68 \pm 0.92$ & $2.82 \pm 0.66$ \\
\hline Nitrogen free extract & $63.90 \pm 1.87$ & $61.66 \pm 2.41$ & $41.90 \pm 1.43$ \\
\hline \hline Total ash & $9.31 \pm 0.73$ & $4.20 \pm 0.86$ & $14.91 \pm 0.84$ \\
\hline
\end{tabular}


Table 2 Proximate composition (\% on DM basis) of experimental diet.

\begin{tabular}{|l|c|c|c|c|}
\hline \multirow{2}{*}{ Constituents } & I & II & III & IV \\
\hline Dry matter & 52.32 & 48.52 & 44.73 & 40.93 \\
\hline Organic matter & 92.69 & 92.41 & 92.13 & 91.85 \\
\hline Total ash & 7.32 & 7.59 & 7.88 & 8.16 \\
\hline Crude protein & 19.63 & 19.71 & 19.80 & 19.88 \\
\hline Crude fibre & 4.34 & 5.12 & 5.89 & 6.67 \\
\hline Ether extract & 8.06 & 8.02 & 7.98 & 7.94 \\
\hline \hline Nitrogen free extract & 60.58 & 59.48 & 58.38 & 57.28 \\
\hline
\end{tabular}

Table 3 Effect of different treatments on daily dry matter intake $(\mathrm{kg})$ of finisher pigs.

\begin{tabular}{|c|c|c|c|c|c|}
\hline \multicolumn{6}{|c|}{ Groups/Treatments } \\
\hline Week & I & II & III & IV & Significance \\
\hline $1^{\text {st }}$ & $2.97 \pm 0.07^{\mathrm{a}}$ & $2.31 \pm 0.08^{\mathrm{b}}$ & $2.38 \pm 0.05^{\mathrm{b}}$ & $2.29 \pm 0.05^{\mathrm{b}}$ & $* *$ \\
\hline $2^{\text {nd }}$ & $3.12 \pm 0.08^{\mathrm{a}}$ & $2.21 \pm 0.08^{b}$ & $2.26 \pm 0.04^{\mathrm{b}}$ & $2.19 \pm 0.06^{\mathrm{b}}$ & $* *$ \\
\hline $3^{\text {rd }}$ & $3.24 \pm 0.17^{\mathrm{a}}$ & $2.27 \pm 0.07^{\mathrm{b}}$ & $2.27 \pm 0.06^{\mathrm{b}}$ & $2.22 \pm 0.05^{\mathrm{b}}$ & $* *$ \\
\hline $4^{\text {th }}$ & $3.30 \pm 0.17^{\mathrm{a}}$ & $2.13 \pm 0.07^{\mathrm{b}}$ & $2.07 \pm 0.05^{\mathrm{b}}$ & $2.14 \pm 0.05^{\mathrm{b}}$ & $* *$ \\
\hline $5^{\text {th }}$ & $3.13 \pm 0.14^{\mathrm{a}}$ & $2.05 \pm 0.06^{\mathrm{b}}$ & $2.04 \pm 0.03^{\mathrm{b}}$ & $2.01 \pm 0.04^{\mathrm{b}}$ & $* *$ \\
\hline $6^{\text {th }}$ & $3.08 \pm 0.17^{\mathrm{a}}$ & $2.10 \pm 0.06^{\mathrm{b}}$ & $2.10 \pm 0.03^{\mathrm{b}}$ & $2.04 \pm 0.04^{\mathrm{b}}$ & $* *$ \\
\hline $7^{\text {th }}$ & $3.09 \pm 0.13^{\mathrm{a}}$ & $2.21 \pm 0.06^{\mathrm{b}}$ & $2.10 \pm 0.03^{\mathrm{b}}$ & $2.00 \pm 0.05^{\mathrm{b}}$ & $* *$ \\
\hline $8^{\text {th }}$ & $3.15 \pm 0.12^{\mathrm{a}}$ & $2.30 \pm 0.06^{\mathrm{b}}$ & $2.18 \pm 0.03^{\mathrm{bc}}$ & $2.07 \pm 0.05^{\mathrm{c}}$ & $* *$ \\
\hline Overall Mean & $3.14 \pm 0.04^{\mathrm{a}}$ & $2.20 \pm 0.03^{\mathrm{b}}$ & $2.18 \pm 0.04^{\mathrm{b}}$ & $2.12 \pm 0.04^{\mathrm{b}}$ & $* *$ \\
\hline
\end{tabular}

Mean \pm S.E. Means bearing different superscripts in a row differ significantly from each other $(* * \mathrm{P}<0.01)$

Table 4 Effect of different treatments on fortnightly body weight change $(\mathrm{kg})$ of finisher pigs.

\begin{tabular}{|c|c|c|c|c|c|}
\hline \multicolumn{6}{|c|}{ Groups/Treatments } \\
\hline Fortnight & $\mathrm{I}$ & II & III & IV & Significance \\
\hline 0 & $43.75 \pm 1.78$ & $45.58 \pm 2.19$ & $45.33 \pm 1.13$ & $47.50 \pm 1.52$ & NS \\
\hline $1^{\text {st }}$ & $54.33 \pm 2.11$ & $53.92 \pm 1.97$ & $53.00 \pm 0.93$ & $56.17 \pm 1.42$ & NS \\
\hline $2^{\text {nd }}$ & $63.08 \pm 2.22$ & $62.50 \pm 2.24$ & $60.58 \pm 0.38$ & $65.42 \pm 1.41$ & NS \\
\hline $3^{\text {rd }}$ & $74.08 \pm 2.84$ & $70.50 \pm 2.36$ & $68.83 \pm 0.54$ & $73.42 \pm 1.34$ & NS \\
\hline $4^{\text {th }}$ & $85.25 \pm 2.74^{\mathrm{a}}$ & $78.58 \pm 2.32^{\mathrm{b}}$ & $77.08 \pm 0.58^{\mathrm{b}}$ & $80.92 \pm 1.43^{\mathrm{ab}}$ & $*$ \\
\hline Overall Mean & $64.10 \pm 7.27$ & $62.22 \pm 5.84$ & $60.96 \pm 5.61$ & $64.69 \pm 5.95$ & NS \\
\hline
\end{tabular}

Mean \pm S.E. Means bearing different superscripts in a row differ significantly from each other $(* * \mathrm{P}<0.01)$

Table 5 Effect of different treatments on daily body weight gain $(\mathrm{g})$ of finisher pigs .

\begin{tabular}{|c|c|c|c|c|c|}
\hline \multicolumn{6}{|c|}{ Groups/Treatments } \\
\hline Fortnight & $\mathrm{I}$ & II & III & IV & Significance \\
\hline $1^{\mathrm{st}}$ & $755.95 \pm 38.48^{\mathrm{a}}$ & $595.24 \pm 34.09^{\mathrm{b}}$ & $583.33 \pm 56.59^{b}$ & $619.05 \pm 17.66^{b}$ & $*$ \\
\hline $2^{\text {nd }}$ & $625.00 \pm 17.86$ & $613.10 \pm 38.48$ & $541.67 \pm 45.57$ & $660.72 \pm 12.20$ & NS \\
\hline $3^{\text {rd }}$ & $785.71 \pm 52.16^{\mathrm{a}}$ & $571.43 \pm 39.12^{b}$ & $589.26 \pm 56.66^{\mathrm{b}}$ & $571.43 \pm 27.66^{\mathrm{b}}$ & $* *$ \\
\hline $4^{\text {th }}$ & $797.62 \pm 38.76^{\mathrm{a}}$ & $577.38 \pm 31.16^{\mathrm{b}}$ & $589.29 \pm 34.19^{b}$ & $535.71 \pm 15.97^{b}$ & $* *$ \\
\hline Overall Mean & $741.07 \pm 39.67^{\mathrm{a}}$ & $589.29 \pm 9.41^{\mathrm{b}}$ & $575.89 \pm 11.49^{b}$ & $596.73 \pm 27.32^{b}$ & $* *$ \\
\hline
\end{tabular}

Mean \pm SE, Means bearing different superscripts in a row differ significantly from each other $(* * \mathrm{P}<0.01$, $* \mathrm{P}<0.05)$, NS $=$ Non-significant

The mean fortnightly changes in body weight $(\mathrm{kg})$ of finishers pig during experimental feeding trial were presented in Table 4. At the end of finishing stage group I showed highest body weight gain followed by groups IV, II and III. It was observed that during first three fortnights, body weight gain did not differ significantly among experimental animals. However, only in Group I, significant $(\mathrm{P}<0.05)$ bodyweight gain was noticed in last fortnight [Fourth] period. The other groups viz., II, III, IV did not show any significant difference in body weight gain. 
Table 6 Effect of different treatments on fortnightly Feed Conversion Ratio of finisher pigs.

\begin{tabular}{|c|c|c|c|c|c|}
\hline \multicolumn{6}{|c|}{ Groups/Treatments } \\
\hline Fortnight & $\mathrm{I}$ & II & III & IV & Significance \\
\hline $1^{\mathrm{st}}$ & $4.06 \pm 0.17$ & $3.89 \pm 0.32$ & $4.58 \pm 0.12$ & $3.52 \pm 0.12$ & NS \\
\hline $2^{\text {nd }}$ & $4.27 \pm 0.21$ & $3.69 \pm 0.34$ & $4.14 \pm 0.33$ & $3.30 \pm 0.09$ & NS \\
\hline $3^{\text {rd }}$ & $3.49 \pm 0.28$ & $3.74 \pm 0.33$ & $3.75 \pm 0.49$ & $3.54 \pm 0.23$ & $\mathrm{NS}$ \\
\hline $4^{\text {th }}$ & $3.95 \pm 0.20$ & $3.96 \pm 0.24$ & $3.68 \pm 0.20$ & $3.82 \pm 0.17$ & $\mathrm{NS}$ \\
\hline Overall Mean & $3.94 \pm 0.17$ & $3.82 \pm 0.06$ & $4.04 \pm 0.21$ & $3.55 \pm 0.11$ & NS \\
\hline
\end{tabular}

Mean \pm SE, Means bearing different superscripts in a row differ significantly from each other $\left({ }^{*} \mathrm{P}<0.05\right), \mathrm{NS}=$ Non-significant

Overall body weight gain during finishing stage was $64.10 \pm$ $7.27,62.22 \pm 5.84,60.96 \pm 5.61$ and $64.69 \pm 5.95$ for group I, II, III and IV, respectively. However the difference among groups was non-significant.

Reduced weight gain with increase in proportion of green berseem in diet might be due to low intake of protein and energy, ultimately resulted in lower growth rate. Nileson (1964), Robinson et al. (1964) and Ranjhan et al. (1972) reported a higher rate of live weight gain in pigs fed rations containing high level of energy. The results were in close agreement with the findings of Yadav et al. (1993), Singh \& Devi (1998), Manh et al. (2002) and Phiny et al. (2010).

The average daily body weight gain for finisher pigs during entire experimental period was presented in Table 5. Overall average daily weight gain in groups I, II, III and IV was 741.07 $\pm 39.67,589.29 \pm 9.41,575.89 \pm 11.49$ and $596.73 \pm 27.32 \mathrm{~g}$, respectively during finishing stage. The difference among groups were highly significant $(\mathrm{P}<0.01)$. Significantly highest daily weight gain were observed for group I followed by group IV, II and III however, no significant difference were observed among later three groups i.e. group II, III and IV. Similar pattern were observed during whole experimental period of finisher stage except during $2^{\text {nd }}$ fortnight, where no significant difference were observed among all groups.
Reduced daily weight gain with increase in proportion of green berseem in diet might be due to low DM intake. The findings of the present study corroborated with the results of Yadav et al. (1993), Silva et al. (2005) and Phiny et al. (2010) who conducted experiment in pigs using mulberry leaves, grass and fodder radish (Raphanus sativus L.) respectively. Results were also in agreement with Sinha et al. (1992).

Average fortnightly feed conversion ratio (FCR) in pigs during finishing stage was presented in Table 6 . The overall average FCR during finishing stage was $3.94 \pm 0.17,3.82 \pm 0.06,4.04$ \pm 0.21 and $3.55 \pm 0.11$, respectively in groups I, II, III and IV and the differences among groups was found to be nonsignificant. During finishing stage, replacement of concentrate for green berseem and kitchen waste decreased FCR value.

However, FCR did not differ significantly among treatment groups during entire experimental period. Decreased FCR value with increase of green berseem in diet in different groups might be due to positive effect on digestive processes and nutrient metabolism (Kroismayr, 2008). The results were in close agreement with findings of Geethapriya et al. (2006) and Manh et al. (2002). On the contrary Yadav et al. (1993) observed increased FCR value with increase in fodder radish in the diet.

Table 7 Relative economics of finisher pigs under different treatments.

\begin{tabular}{|c|c|c|c|c|c|}
\hline \multicolumn{6}{|c|}{ Groups/Treatments } \\
\hline Particulars & $\mathbf{I}$ & II & III & IV & Significance \\
\hline $\begin{array}{l}\text { Cost of total Concentrate } \\
\text { feed intake (Rs.) }\end{array}$ & $820.82 \pm 24.29^{\mathrm{a}}$ & $516.82 \pm 8.36^{\mathrm{b}}$ & $447.83 \pm 2.92^{\mathrm{c}}$ & $358.73 \pm 7.84^{\mathrm{d}}$ & $* *$ \\
\hline $\begin{array}{l}\text { Cost of total kitchen } \\
\text { waste intake (Rs.) }\end{array}$ & $152.17 \pm 5.41^{\mathrm{a}}$ & $110.81 \pm 2.10^{\mathrm{b}}$ & $109.15 \pm 1.31^{\mathrm{b}}$ & $107.32 \pm 2.57^{\mathrm{b}}$ & $* *$ \\
\hline $\begin{array}{l}\text { Cost of total berseem } \\
\text { intake (Rs.) }\end{array}$ & $85.18 \pm 2.19^{\mathrm{a}}$ & $96.14 \pm 2.52^{b}$ & $131.46 \pm 1.70^{\mathrm{c}}$ & $165.46 \pm 3.18^{\mathrm{d}}$ & $* *$ \\
\hline $\begin{array}{l}\text { Cost of total feedintake } \\
\text { (Rs.) }\end{array}$ & $1058.17 \pm 31.56^{\mathrm{a}}$ & $723.76 \pm 12.25^{b}$ & $688.44 \pm 4.92^{b}$ & $631.50 \pm 13.39^{c}$ & $* *$ \\
\hline $\begin{array}{l}\text { Total body weight gain } \\
(\mathrm{Kg})\end{array}$ & $41.50 \pm 1.60^{\mathrm{a}}$ & $33.00 \pm 1.20^{\mathrm{b}}$ & $31.75 \pm 1.31^{\mathrm{b}}$ & $33.42 \pm 0.76^{\mathrm{b}}$ & $* *$ \\
\hline $\begin{array}{l}\text { Cost per kg live weight } \\
\text { gain (Rs./kg) }\end{array}$ & $25.65 \pm 1.05^{\mathrm{a}}$ & $22.03 \pm 0.60^{\mathrm{b}}$ & $21.86 \pm 0.88^{b}$ & $18.95 \pm 0.60^{\mathrm{c}}$ & $* *$ \\
\hline
\end{tabular}

Means bearing different superscripts in a row differ significantly from each other $(* * \mathrm{P}<0.01)$ 
Table 7 represents relative economics for rearing pigs using different levels of green berseem along with concentrate and fixed level of kitchen waste. Significantly $(p<0.01)$ highest cost of balanced ration was observed for group I $(820.82 \pm$ 24.29) followed by group II $(516.82 \pm 8.36)$, III $(447.83 \pm$ 2.92) and group IV (358.73 \pm 7.84$)$, which differ significantly among each other. The cost involved in feeding kitchen waste for group I, II, III and IV was Rs. $152.17 \pm 5.41,110.81 \pm$ $2.10, \quad 109.15 \pm 1.31$ and $107.32 \pm 2.57$ respectively, significantly $(\mathrm{p}<0.01)$ highest value was observed for group I, however no significant difference were observed among groups II, III and IV. The cost of feeding green berseem was found less in Group I (Rs. $85.18 \pm 2.19$ ) and highest in Group IV (Rs. $165.46 \pm 3.18$ ). In all these groups, this parameter differed significantly in this experimental study.

The total cost of feeding during the whole experiment was significantly $(\mathrm{P}<0.01)$ highest in group I (Rs. 1058.17), followed by group II (Rs. 723.76), group III (Rs. 688.44) and lowest in group IV (Rs. 631.50). Cost involved for production of $1 \mathrm{~kg}$ live weight for group I to IV was Rs. 25.65, Rs. 22.03, Rs. 21.86 and Rs. 18.95 respectively, which differ Significantly $(\mathrm{P}<0.01)$ among groups but non-significant between group II and III. The highest cost per $\mathrm{kg}$ live weight gain in group I was due to highest dry matter and maximum concentrate intake. Non-significant but higher cost involved in group II as compared to group III due to relatively more concentrate intake. Provision of green berseem along with kitchen waste and balanced ration decreased the cost per $\mathrm{kg}$ live weight gain.

\section{Conclusion}

The result demonstrated a clear advantage of replacement of concentrate with green berseem and kitchen waste both in rate and economy of weight gain in respect of profit per $\mathrm{kg}$ of pork production. Thus it may be concluded that, Green berseem could be incorporated upto $25 \%$ of total dry matter intake without affecting performance of pigs adversely.

\section{Conflict of interest}

Authors would hereby like to declare that there is no conflict of interests that could possibly arise.

\section{References}

Geethapriya L, Rao DS, Ravi A, Reddy RR, Rao ZP (2006) Growth performance and nutrient digestibility of rations containing dried amaranthus (A. cruentus) whole plant meal. Indian Journal of Animal Nutrition 16: 332-335

ICAR (2002) Hand book of animal husbandry. Indian Council of Agricultural Research, KrishiAnusandhan Bhavan, Pusa, New Delhi.
Kroismayr A (2008) Lignocellulose- fresh wood as dietary fibre. Pig progress $24: 78$.

Manh LH, Dung NNX, Men LT, Takada R, Yamasaki S (2002) Replacement of Concentrate Protein by Water Spinach (Ipomoea aquatica) on digestibility, feed intake and liveweight gain in growing pigs. Doctoral thesis submitted to Department of Animal Husbandry, Faculty of Agriculture, Cantho University, Cantho, Vietnam.

Nileson HE (1964) Effect of bacon pigs of different levels of nutrition to $20 \mathrm{~kg}$ body weight. Animal Science 6 : 301-308. DOI: http://dx.doi.org/10.1017/S0003356100022091.

Phiny C, Preston T R and Borin K 2010: Effect of fresh mulberry leaves and sweet potato vines on growth performance of pigs fed a basal diet of broken rice. Livestock Research for Rural Development 22, Article \#44. Retrieved October 9, 2016, from http://www.lrrd.org/lrrd22/3/phiny22044.htm

Ranjan SK, ShuklaVP, Kumar I, Pathak NN, Joshi BC (1972) Effect on growth rate and carcass composition in Large White Yorkshire pigs on various planes of nutrition during growingfinishing periods. Indian Journal of Animal Science 42: 45358.

Robinson DW, MorganJTJ, Lewis D (1964) Protein and energy nutrition of the pigs. 1. The effect of varying protein and energy levels in the diets of growing pigs. Journal of Agricultural Science $62: 369-76$.

Silva SP, João MA, Enes FO, Figueiredo C, Pires, José S, Abreu JM (2005) Grass utilization in growing finishing bísaro pigs $(85-107 \mathrm{~kg})$ performance and carcass composition. In : Poster presented at III Symposium International sur le PorcMéditerranéen, Tarbes - France.

Singh SK, Devi AA(1998) Effect of grasses fed to pigs by different methods on their growth rate and feed conversion efficiency. Indian Journal of Animal Sciences 68 : 693-695.

Sinha SK, Singh RA, Sharma BD (1992) Effect of replacing cereals on some carcass traits and economics of swine production under rural management. Indian Journal of Animal Sciences $62: 273-277$.

Snedecor GW, Cochran WG(1994) Statistical methods. $8^{\text {th }}$ ed. Iowa state University press. pp. 217-235.

Yadav BPS, Varma A, Gupta JJ (1990) Green maize fodder feeding to pigs. Indian Journal of Animal Sciences 60: 11271128.

Yadav BPS, Varma A, Gupta JJ (1993) Effect of feeding fodder radish (Raphanussativus L.) as a partial replacement of concentrate component in swine rations. Indian Journal of Animal Sciences 63 : 1202-1205. 